\title{
Role Playing untuk Meningkatkan Kemampuan Berbicara pada Anak Kelompok A Taman Kanak-Kanak
}

\author{
Regina Christine Takumansang ${ }^{1}$, Triyono $^{2}$, Sulthoni $^{3}$ \\ ${ }^{1}$ Pendidikan Anak Usia Dini-Universitas Negeri Malang \\ ${ }^{2}$ Bimbingan dan Konseling-Universitas Negeri Malang \\ ${ }^{3}$ Teknologi Pembelajaran-Universitas Negeri Malang
}

\begin{tabular}{l}
\hline INFO ARTIKEL \\
\hline Riwayat Artikel: \\
Diterima: $15-07-2019$ \\
Disetujui: $12-02-2020$ \\
\hline
\end{tabular}

Kata kunci:

role playing;

speaking ability

early childhood;

role playing;

kemampuan berbicara;

anak usia dini

\begin{abstract}
Speaking ability is one of the aspect in language development, which is vital to be planted since young age. The purpose of this research are (1) to describe the role playing practice in order to elevate the speaking ability of Group A in TK Ananda Kota Batu, (2) to describe the enhancement of speaking ability of Group A through role playing practice in TK Ananda Kota Batu. This research used "Penelitian Tindakan Kelas (Classroom Action Research). This research utilize 2 cycle of data processing which allows each data is processed using qualitative analysis and quantitative analysis. The result of this research shows that there is an increase of speaking ability for child from cycle I to cycle II.
\end{abstract}

ABSTRAK

\begin{abstract}
Abstrak: Kemampuan berbicara merupakan salah satu aspek perkembangan bahasa yang perlu ditanamkan sejak anak usia dini. Tujuan dari penelitian ini untuk (1) mendeskripsikan penerapan role playing dalam meningkatkan kemampuan berbicara pada anak kelompok A TK Ananda Kota Batu (2) mendeskripsikan peningkatan kemampuan berbicara anak kelompok A melalui penerapan role playing di TK Ananda Kota Batu. Penelitian ini menggunakan Peneilitian Tindakan Kelas. Penelitian ini menggunakan dua siklus dimana setiap siklus analisis data yang digunakan menggunakan analisis kualitatif dan kuantitatif. Instrumen penelitian ini menggunakan lembar observasi. Hasil dari penelitian ini menunjukkan bahwa kemampuan berbicara anak dari siklus I sampai II terjadi peningkatan.
\end{abstract}

\section{Alamat Korespondensi:}

Regina Christine Takumansang

Pendidikan Anak Usia Dini

Universitas Negeri Malang

Jalan Semarang 5 Malang

E-mail: regina.christine15@gmail.com

Pendidikan anak usia dini bertujuan untuk mengembangkan semua aspek perkembangan pada anak secara seimbang. Aspekaspek perkembangan anak usia dini antara lain terdiri dari apek perkembagan nilai moral dan agama, kognitif, bahasa, seni, sosial emosional, dan fisik motorik. Pernyataan tersebut didukung oleh Undang-Undang RI Nomor 20 Tahun 2003 mengenai Sistem Pendidikan Nasional Pasal 28 Ayat 3, yaitu PAUD bertujuan membantu anak didik mengembangkan berbagai potensi baik fisik maupun psikis yang meliputi nilai agama dan moral, sosial, emosional, kognitif, bahasa, motorik, dan seni.

Pendidikan anak usia dini merupakan pemberi andil untuk meningkatkan mutu sumber daya manusia. Anak berada pada fase emas dimana perkembangan anak sangat pesat, baik menyangkut pertumbuhan fisik dan motoriknya, pekembangan karakter dan moralnya, serta emosional dan intelektualnnya (Ningsih, 2013). Pengembangan aspek yang perlu dikembangkan dan dilatih pada anak sejak usia dini, salah satunya adalah kemampuan berbicara. Kemampuan berbicara pada anak sangat penting kraena pada masa ini komunikasi mereka mulai berkembang untuk berbagai situasi sosial serta pembelajaran. Anak memerlukan kemampuan berbicara agar dapat mengekspresikan diri dalam hal mengungkapkan perasaan, pendapat, beragumen, dan berkomunikasi dengan orang lain.

Berbicara pada hakikatnya merupakan keterampilan mereproduksi arus sistem bunyi artikulasi untuk menyampaikan kehendak, kebutuhan perasaan, dan keinginan kepada orang lain. Keterampilan berbicara sebagai keterampilan berbahasa yang sifatnya produktif, menghasilkan, memberi, atau menyampaikan. Pembicara menyampaikan informasi kepada orang lain (penyimak), pembicara fungsinya sebagai komunikator dan penyimak sebagai komunikan (Ernani \& Syarifuddin, 2016). Kemampuan berbicara yang dimiliki anak merupakan sebuah alat bersosialisasi sehingga anak dapat berteman dan melatih kemandiriannya (Hurlock, 1991).

Kemampuan berbicara adalah aspek perkembangan bahasa yang penting dalam kehidupan anak, karena sebagai makhluk sosial berbicara adalah salah satu tuntutan kebutuhan hidup. Hal tersebut diperkuat oleh pendapat Djiwandono dimana seseorang dapat mengungkapkan pikiran serta perasaannya secara lisan dengan berbicara kepada orang lain sehingga terjadi 
proses sosialisasi (Djiwandono, 2016). Jadi, dapat disimpulkan bahwa kemampuan berbicara anak usia dini memiliki tujuan supaya anak lancar berkomunkasi lisan dan memiliki kemampuan berbicara yang baik. Tujuan umum dari pengembangan kemampuan berbicara anak, meliputi (1) anak dapat mengucapkan bunyi bahasa yang akan digunakan dengan tepat; (2) anak memiliki kosakata yang cukup untuk kebutuhan berkomunikasi; (3) anak dapat menerapkan kalimat untuk berkomunikasi dengan tuturan lisan (Suhartono, 2015).

Kemampuan berbicara anak usia dini masuk dalam aspek perkembangan bahasa. Pada usia tersebut kemampuan berbahasa anak mempunyai karakteristik seperti mengenal beberapa kosakata, sudah dapat berbicara lancar dengan kalimat sederhana, menceritakan kembali cerita yang di dengar, serta menjawab dan membuat pertanyaan sederhana. Ada beberapa manfaat yang didapatkan anak jika memiliki kemampuan berbicara yang memadai yaitu, anak bisa menyampaikan berbagai hal, dapat menyampaikan kemauan dan keinginan, serta dapat mengungkapkan berbagai perasaan (Sudarminah, 2009).

Kemampuan berbicara pada anak usia dini kelompok A TK Ananda Kota Batu masih perlu ditingkatkan. Dibuktikan dari hasil pengamatan yang telah dilakukan peneliti. Rendahnya kemampuan berbicara pada anak dapat dilihat dari (1) anak diam cukup lama saat guru bertanya sehingga guru perlu mengeja kembali pertanyaannya; (2) anak tidak dapat menjawab pertanyaan secara spontan; (3) anak menangis saat diganggu temannya, tidak berani melapor pada guru; (4) anak mengompol di dalam kelas, tidak berani minta ijin kepada guru; (5) anak belum dapat menceritakan kembali secara singkat isi cerita yang didengar; (6) anak belum dapat mengulang kalimat sederhana yang dicontohkan.

Hasil observasi yang ditemukan memotivasi peneliti sehingga menjalankan penelitian sehingga kemampuan berbicara anak kelompok A TK Ananda Batu meningkat. Menurut (Hurlock, 1991) meniru merupakan salah satu cara anak untuk dapat berbicara, yaitu anak memperhatikan orang dewasa maupun teman sebayanya, serta latihan dengan tuntunan orang yang lebih tua. Oleh karena itu, pemilihan metode harus disesuaikan dengan tujuan tindakan di dalam kelas.

Metode yang digunakan dalam penelitian ini adalah role playing. Smilansky mengungkapkan bahwa role playing perlu diterapkan pada anak untuk menstimulasi kemampuan berbicara sehingga anak mampu merangkai kalimat dan melakukan percakan dengan teman sebaya (Rumilasari, Tegeh, \& Ujianti, 2016). Menurut (Dewi, 2017) penerapan role playing membutuhkan waktu yang cukup banyak dalam persiapan dan pelaksanaannya, oleh karena itu harus merencanakan dan mengatur waktu dengan baik agar model ini dapat diterapkan dengan efektif. Selain itu, dalam penerapan role playing diperlukan persiapan skenario yang tepat dan menarik agar materi dapat tersampaikan dengan baik.

Role playing dipilih sebagai metode dalam penelitian ini karena metode ini adalah sejenis permainan yang memiliki tujuan, aturan, gerakan tubuh, serta menyenangkan bagi anak. Role playing ialah bentuk kegiatan pembelajaran dimana seseorang mengandaikan dirinya memainkan peran sebagai orang lain (Abdurrahman, 2012). Berdasarkan paparan latar belakang, maka penelitian ini bertujuan menerapkan role playing untuk meningkatkan kemampuan berbicara anak usia dini kelompok B TK Ananda Kota Batu.

\section{METODE}

Penelitian ini menggunakan rancangan penelitian tindakan kelas dikarenakan penelitian ini berpusat pada peningkatan kemampuan berbicara anak dengan menggunakan role playing. Penelitian tindakan kelas adalah penelitian yang bertujuan untuk meningkatkan kualitas proses dan hasil pembelajaran di kelas yang dilakukan secara bersiklus. Model Penelitian Tindakan Kelas yang digunakan merupakan model penelitian tindakan kelas yang dikembangkan oleh (Kemmis \& Taggart, 2010). Setiap siklus terdiri atas: planning (perencanaan), acting and observing (tindakan dan pengamatan), reflecting (perefleksian), dan revision plan (rencana perbaikan).

Jenis pelaksanaan tindakan kelas ini adalah kolaborasi antara peneliti dan guru. Pemilihan kolaborasi ini dapat membantu guru maupun peneliti untuk mengatasi masalah kemampuan berbicara anak. Pelaksanaan penelitian dilaksanakan selama dua siklus, setiap siklusnya terdapat empat kali pertemuan. Penelitian ini dilakukan pada kelompok A TK Ananda Kota Batu yang dilaksanakan pada semester II tahun ajaran 2018/2019 pada bulan Februari 2019. Subjek penelitian adalah anak-anak kelompok A TK Ananda Kota Batu yang berjumlah 18 anak. Teknik pengumpulan data yang digunakan adalah observasi. Observasi adalah suatu bentuk kegiatan untuk meninjau proses yang sedang terjadi, dalam hal ini adalah untuk mengetahui kemampuan berbicara anak.

Analisis data pada penelitian ini dilakukan dengan cara kualitatif dan kuantitatif. Kegiatan analisis data menggunakan observasi, dokumentasi, catatan observer dan guru dalam kegiatan pelaksanaan kegiatan role playing. Hasil observasi terhadap kemampuan berbicara kemudian direfleksikan dan dianalisis. Peningkatan anak dalam kemampuan berbahasa melalui role playing terdapat beberapa komponen pada lembar observasi, yaitu (1) mengulang kalimat sederhana; (2) mengungkapkan perasaan senang dan sedih; (3) mengutarakan pendapat kepada guru dan teman; (4) menjawab sesuai dengan pertanyaan; (5) menceritakan kembali cerita/dongeng yang pernah didengar.

Berdasarkan kriteria penilaian yang telah ditentukan maka dapat dikatakan kriteria keberhasilan atau ketuntasan kelas adalah jika anak mampu mencapai indikator sama dengan atau lebih besar dari sama dengan $72 \%$ atau lebih dari 13 anak. Berarti jika saat siklus pertama kemampuan berbicara anak dalam satu kelas belum mencapai ketuntasan kelas sama dengan atau lebih dari $72 \%$ atau kurang dari 13 anak, maka akan ada siklus kedua. Tujuan dari siklus-siklus yang dilakukan tersebut untuk memperbaiki proses kegiatan guru dan peneliti guna mencapai tujuan. 


\section{HASIL}

Hasil observasi yang dilakukan sebelum pelaksanaan tindakan menunjukkan kemampuan berbicara anak kelompok A di TK Ananda Kota Batu masih tergolong kurang. Kemampuan berbicara anak 11 dari 18 anak kelompok A kurang maksimal. Hal tersebut diketahui dari hasil evaluasi yang menunjukkan dari 18 anak, yang memiliki kemampuan berbicara yang baik berjumlah tujuh anak (39\%), sedangkan sebelas anak (61\%) memiliki kemampuan berbicara yang masih rendah. Setelah dilaksanakan role playing pada siklus I pada tanggal 4 Februari 2019 hasil yang dicapai anak dalam role playing untuk mengingkatkan kemampuan berbicara anak kelompok A TK Ananda Kota Batu adalah 61,11\% (11 anak) yang masuk dalam kategori $72-100 \%$ atau berhasil, sedangkan tujuh anak masih masuk dalam kategori rentang nilai kurang dari $72 \%$ atau belum berhasil. Dari pelaksanaan siklus I ini dapat diketahui bahwa masih ada tujuh anak yang kriteria ketuntasannya belum sesuai target yang ingin dicapai, untuk itu menurut perolehan tindakan pada siklus I peneliti merancang perbaikan menggunakan inovasi dalam kegiatan pembelajaran yang akan diterapkan pada siklus II. Siklus II dilaksanakan pada tanggal 4 Maret 2019.

Kegiatan di siklus II memiliki persentase ketuntasan $88,89 \%$ dan sekor rata-rata kemampuan berbicara anak pada siklus II mencapai skor 84,72. Dari pelaksanaan siklus II ini masih ada dua anak dimana ketuntasan yang ditetapkan berlum tercapaikarena kondisi anak mengalami hambatan dalam melakukan kegiatan. Pelaksanaan siklus II dikatakan telah tercapai karena persentase ketuntasan kelas memperoleh 88,89\% dan mengalami peningkatan sebesar 49,89\% dari kegiatan pra tindakan. Kondisi ini memperlihatkan bahwa ketuntasan klasikal pada siklus II telah memperoleh standar keberhasilan yang diharapkan yakni minimal $72 \%$.

Berdasarkan pada paparan data tentang proses pelaksanaan role playing pada anak kelompok A TK Ananda Kota Batu, maka terdapat beberapa peningkatan dalam proses kegiatan di kelas. Peningkatan tersebut ditandai dengan meningkatnya kemampuan berbicara anak dalam menjawab pertanyaan, mengungkapkan perasaan, menceritakan kembali isi cerita/dongeng, mengulang kalimat sederhana, serta mengutarakan pendapat pada guru dan teman sebaya. Peningkatan kemampuan berbahasa anak dari sebelum siklus, siklus I sampai II tersaji pada gambar 1.

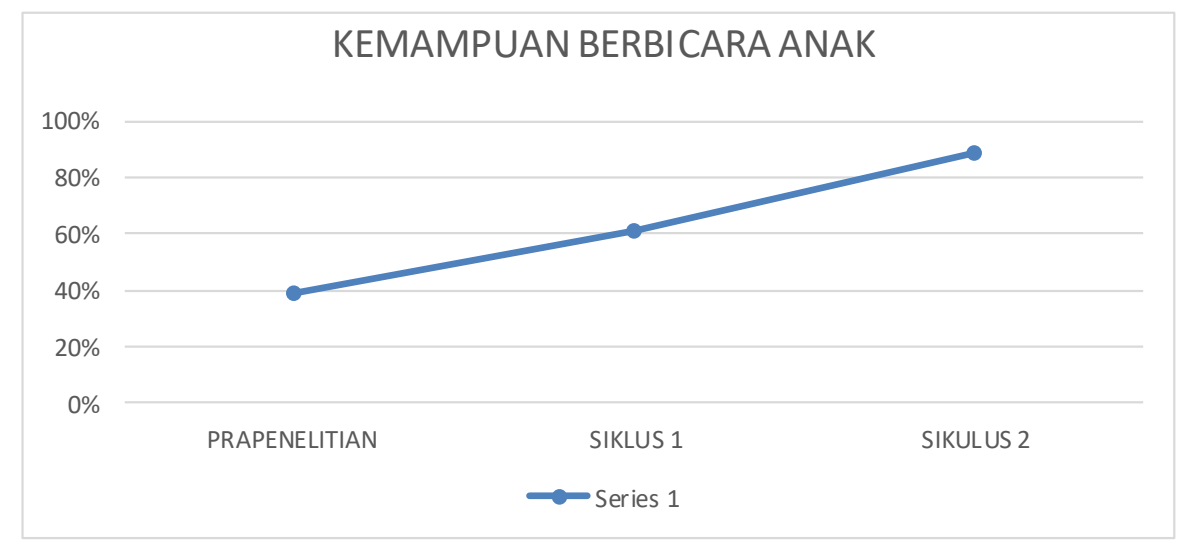

Gambar 1. Grafik Perbandingan Rekapitulasi Hasil Pelaksanaan

Dari hasil penelitian diketahui bahwa melalui role playing kemampuan berbicara anak Kelompok A TK Ananda Kota Batu terjadi peningkatan sebanyak $49,89 \%$ dari kegiatan sebelum tindakan sampai tindakan siklus II. Tingkat keberhasilan kelompok A pada siklus II sebesar $88,89 \%$ yang berarti tingkat keberhasilan sudah melebihi kriteria yang diharapkan, yaitu lebih dari sama dengan $72 \%$.

\section{PEMBAHASAN}

Meningkatkan kemampuan anak dalam berbicara sejak usia dini dimaksudkan supaya anak mampu berkomunikasi dengan orang lain sebagai bekal kehidupan anak dalam lingkungan sosial. Mengungkapkan kemampuan berbicara yang dimiliki anak merupakan sebuah alat bersosialisasi sehingga anak bisa berteman dan melatih kemandiriannya (Hurlock, 1991). Oleh sebab itu, kemampuan berbicara anak sangat penting dikembangkan untuk kecakapan hidup berinteraksi dengan orang lain. Anak dengan kemampuan berbicara yang baik memperlihatkan bahwa anak siap belajar ke jenjang selanjutnya. Hal ini terlihat dari intelegensi anak yang semakin cerdas dan cepat menguasai kosakata, serta keberanian anak berinteraksi dengan orang lain. Hasil penelitian ini sangat terlihat pada sikap anak dalam menjawab pertanyaan guru dan sikap anak yang berani bertanya kepada teman sebayanya.

Proses kemampuan berbicara pada anak terus berkembang karena perkembangan berbahasa akan terus berlangsung sepanjang hayat (Hurlock, 2017). Oleh karena itu, perkembangan bahasa tidak berhenti ketika anak bersekolah. Anak pada nantinya akan belajar berbahasa secara formal, mengetahui sejumlah besar kosa kata, dan mengetahui cara berbicara untuk berkomunikasi dengan orang lain. Jika sejak dini perkembangan bahasa anak tidak distimulasi dengan baik sehingga mengakibatkan rendahnya kemampuan berbicara sejak usia dini, maka akan berdampak buruk bagi masa depan anak. 
Kemampuan berbicara pada anak sangat penting karena berbicara adalah salah satu kemampuan yang dianggap sebagai alat kontrol sosial bagi manusia yang menyatakan bahwa berbicara adalah bentuk perilaku manusia yang memanfaatkan faktor fisik, psikologis, neurologis, semantik, dan linguistik yang sangat intensif (Dhieni, Hapidin, \& Ningtias, 2017).

Penerapan role playing ini menuntut anak untuk percaya diri dalam kegiatan di kelas sehingga anak lebih termotivasi, bersemangat, dan aktif. Anak perlu diberi kepercayaan untuk mengatur perilaku, emosi, dan kognisi sehingga kemampuan anak yang sedang tumbuh dapat lebih maksimal (Piotrowski, Lapierre, \& Linebarger, 2013). Dengan diterapkannya role playing maka dapat mendorong anak berinteraksi melalui dialog sehingga anak dapat menyebutkan vokal-vokal pada pelafalan, kalimat agar dapat menyampaikan perasaan, pendapat, dan pikiran (Hamdayama, 2014). Pada pelaksanaan siklus I dan II, role playing sudah dilakukan dan memberikan kenaikan pada kemampun berbicara anak kelompok A TK Ananda Kota Batu. Hasil penelitian ini didukung oleh penelitian terdahulu yang dilakukan oleh (Amri, 2017) mengenai Pengaruh Metode Bermain Peran terhadap Kemampuan Komunikasi (Bahasa Ekspresif) Anak Taman Kanak-Kanak Raudhatul Athfal Alauddin Makassar, menunjukkan hasil bahwa kemampuan bahasa ekspresif anak mengalami peningkatan setelah diberi perlakuan melalui pembelajaran metode bermain peran. Melalui kegiatan bermain peran, keberanian dan rasa percaya diri anak dapat dipupuk apabila kegiatan ini dilakukan secara berulang. Dengan meningkatnya keberanian dan rasa percaya diri anak, maka dapat memberikan pengaruh positif terhadap kelancaran anak dalam berbicara.

Dengan demikian, penerapan role playing mampu membuat kemampuan berbicara anak kelompok A TK Ananda Kota Batu meningkat. Dibuktikan melalui data hasil penelitian yang memperlihatkan kemampuan bicara anak terjadi peningkatan dari siklus I yaitu sebanyak $61,11 \%$ atau 11 anak mampu mendapatkan $\geq$ bintang tiga pada kegiatan bermain peran siklus I dengan skor rata rata 68,98 . Persentase anak yang tuntas pada kegiatan pra penelitian adalah $39 \%$ dan meningkat menjadi $61,11 \%$ di siklus I. Peningkatan berdasarkan data hasil evaluasi pengamatan penelitian. Dari hasil penelitian dapat diketahui bahwa terjadi peningkatan pada kemampuan anak dari kegiatan pratindakan ke siklus II, pada siklus II persentase ketuntasan mencapai $88,89 \%$ atau 16 anak yang mampu mendapatkan $\geq$ bintang tiga pada kegiatan di kelas siklus II menunjukkan skor rata-rata 84,72 .

\section{SIMPULAN}

Hasil penelitian yang dilakukan mengenai penerapan role playing untuk meningkatkan kemampuan berbicara anak kelopok A TK Ananda Kota Batu dapat disimpulkan sebagai berikut. Pertama, hasil penelitian yang telah dilakukan menunjukkan perkembangan yang meningkat dari siklus I yang peningkatan kemampuan berbicara anak masih mencapai $61,11 \%$ yang berarti kemampuan berbicara anak masih rendah atau di bawah standart minimal ketuntasan. Siklus II kemampuan berbicara anak telah mencapai peningkatan yaitu $88,89 \%$ yang berarti telah memenuhi standart yang ditetapkan yaitu sebesar $72 \%$. Anak mengalami peningkatan kemampuan berbicara dari kegiatan pra tindakan ke tindakan siklus II sebesar $49,89 \%$. Kedua, penerapan role playing diterapkan semenarik mungkin, sesuai dengan tema yang menyangkut keseharian anak. Ketiga, tahapan kegiatan role playing pada penelitian ini, yaitu (a) guru memilih masalah sesuai tema yang berkaitan dengan kehidupan anak sehari-hari, (b) memilih karakter, (c) menyusun langkah-langkah permainan dan guru merancang skenario, (e) pemeranan, dimana anak mulai berperan sesuai dengan peran masing, (f) tanya jawab serta evaluasi, dimana terjadi percakapan antara guru dan anak dalam mendiskusikan masalah-masalah yang muncul, dan (g) guru dan anak mengambil kesimpulan dari role playing yang telah dilakukan.

Hasil penelitian ini dapat memberikan input bagi sekolah dalam rangka perbaikan proses pembelajaran guna meningkatkan aspek perkembangan bahasa khususnya kemampuan berbicara anak usia dini pada kelompok A. Hasil penelitian ini juga dapat memberikan input bagi kepala sekolah untuk menyediakan sarana dan prasarana sekolah bagi guru dalam melaksanakan metode role playing. Selain itu, dengan dilaksanakannya penelitian ini maka diharapkan guru mau menerapkan role playing dan menemukan kreasi baru agar metode ini menjadi lebih inovatif. Guru diharapkan dapat menerapkan role playing aspek-aspek perkembangan anak yang lainnya sehingga seluruh kemampuan anak dapat berkembang secara optimal.

Manfaat bagi anak yaitu dapat meningkatkan kemampuan berbicara anak. Selain itu, diharapkan anak lebih antusis dalam mengikuti kegiatan di dalam kelas yang dirancang oleh guru dengan penerapan media pembelajaran yang ada di sekitar anak. Manfaat penelitian ini bagi peneliti selanjutnya yaitu dapat melatih kreativitas dalam merancang metode pembelajaran yang menarik dan melatih kemampuan dalam mengatasi permasalahan yang muncul di kelas. Sementara itu, saran untuk para orangtua siswa dan pemerhati pendidikan anak usia dini, disarankan mampu menerapkan permainan ini dalam lingkungan keluarga maupun instansi terkait. 


\section{DAFTAR RUJUKAN}

Abdurrahman, M. (2012). Pendidikan bagi Anak Berkesulitan Belajar: Teori, Diagnosis, dan Remediasinya. Jakarta: PT. Rineka Cipta.

Amri, N. A. (2017). Pengaruh Metode Bermain Peran terhadap Kemampuan Komunikasi (Bahasa Ekspresif) Anak Taman Kanak-Kanak Raudhatul Athfal Alauddin Makassar. Jurnal Ilmu Pendidikan, Keguruan, dan Pembelajaran, 1(2), 105110.

Dewi, T. A. (2017). Efektivitas Model Role Playing dalam Meningkatkan Kompetensi Mahasiswa pada Matakuliah Manajemen Keuangan. Jurnal Pendidikan Ekonomi UM Metro, 5(1), 95-104.

Dhieni, N., Hapidin, \& Ningtias, A. A. (2017). The Speaking Ability of Five-to-Six-Year-Old Children in Morning Journal Activity. International Journal of Education and Research, 5(5), 223-230.

Djiwandono M. (2016). Tes Bahasa dalam Pengajaran. Bandung: ITB Bandung.

Ernani., \& Syarifuddin, A. (2016). Pengaruh Metode Role Playing terhadap Keterampilan Berbicara Siswa pada Mata Pelajaran Bahasa Indonesia Kelas V di Madrasah Ibtidaiyah Wathoniyah Palembang. Jurnal Ilmiah PGMI, 2(1), $29-42$.

Hamdayama, J. (2014). Model dan Metode Pembelajaran Kreatif dan Berkarakter. Bogor: Ghalia Indonesia.

Hurlock, E. (1991). Perkembangan Anak. Jakarta: Erlangga.

Hurlock, E. (2017). Psikologi Perkembangan: Suatu Pendekatan Sepanjang Rentang Kehidupan. Jakarta: Erlangga.

Kemmis, \& Taggart, M. (2010). The Action Research Planner. Geelong: Deaken Univercity Press.

Ningsih, E. (2013). Penggunanan Metode Bermain Peran Dalam Menumbuhkan Keterampilan Berbahasa Anak Usia Dini. Jurnal Empowerment, 2(2), 126-136.

Piotrowski, J. T., Lapierre, M. A., \& Linebarger, D. L. (2013). Investigating Correlates of Self-Regulation in Early Childhood with a Representative Sample of English-Speaking American Families. Journal Child Family Study, 22(3), $423-436$.

Rumilasari, N. P. D., Tegeh, I. M., \& Ujianti, P. R. (2016). Pengaruh Metode Bermain Peran (Role Playing) terhadap Kemampuan Berbicara pada Anak Kelompok A. E-Journal Pendidikan Anak Usia Dini, 4(2), 1-11.

Sudarminah, S. (2009). Upaya Peningkatan Pembelajaran Berbicara dengan Model Pembelajaran Gambar Seri untuk Siswa Kelas VIII SMP Negeri 6 Semarang. Jurnal Lemlit, 3(2), 45-52.

Suhartono. (2015). Pengembangan Keterampilan Bicara Anak Usia Dini. Jakarta: Departemen Pendidikan Nasional. 